\title{
Speech Acts of Suggestion by Indonesian Students during Peer Response Activities
}

\author{
Arianty Visiaty ${ }^{1}$, Lusi Lian Piantari ${ }^{2}$ \\ \{ ariantyvisiaty@uai.ac.id ${ }^{1}$, lusi_lian@uai.ac.id² $\}$ \\ ${ }^{1,2} \mathrm{Al}$ Azhar Indonesia University, Kompleks Masjid Agung Jl. Sisingamangaraja, Jakarta, Indonesia
}

\begin{abstract}
This is a pragmatic study, qualitatively describing in particular how learners use speech act strategies in giving suggestions during peer response activity. The study involved 25 Indonesian students of Japanese as a Foreign Language of the intermediate level at the Al Azhar University of Indonesia. The results show that the learners use speech act strategies of direct, conventionalized forms, and indirect. The strategy most widely used by the learners in giving suggestions is the indirect one, i.e. the strategy of giving suggestions indirectly. This shows that the cultural background of the learners, i.e. Indonesian culture, strongly influences the choice of strategy. The mitigation devices used are verbal devices consisting of the opener, specific words as mitigation markers (mungkin, kayaknya, cuma), justification/reason, phatic expression, and closing. Besides, non-verbal devices are also used, such as emoticons and laughing forms.
\end{abstract}

Keywords: Speech act, suggestion, face, cultural background, peer response

\section{Introduction}

Peer response has been carried out many times in foreign language learning classes. According to Ikeda [1], peer response is an activity to correct writings carried out by fellow learners where the learners exchange the roles as readers and authors to improve their proficiency in language skills through peer discussion. The benefits of peer response activity, among others, are to improve writing ability and develop the ability to cooperate with others. However, in reality, the atmosphere of active discussion expected from peer response activity frequently has not been accomplished. Therefore, the results from peer response activity are not sufficiently influential in improving the writing.

Many factors are leading to the ineffectiveness of peer response, i.e. the use of languages affected by the cultural background of the speakers. Most Indonesians are highly cautious when giving suggestions to not offend those given the suggestions. Giving suggestions is one of the pragmatic studies, namely, speech acts discussing the use of language. In giving suggestions, someone should not merely be able to master language skills, but also the social and cultural aspects of the language. Speech acts of suggestion are directive speech acts in which the speakers ask the interlocutors about something that should or should be done or how the interlocutors should act. Giving suggestions is considered to be an act that can make people act/behave better. The theory of speech acts is closely related to the concept of politeness, namely the acts associated with saving "face"[2].

The speech acts of suggestion, while giving benefits to the interlocutors, are still potentially threatening the face of the interlocutors [2]. The failure of the interlocutors to 
perform the suggested actions may result in the speakers being considered to act in a rude, offensive, or disrespectful manner [3]. In this case, the use of mitigation devices is necessary to minimize the possibility of the interlocutors feeling offended. This study examines speech acts of suggestion spoken by the learners in peer response activity using their mother tongue, namely Bahasa Indonesia. The study on speech acts of a suggestion by the learners using their mother tongue has been carried out previously by Farnia, et al [4], namely speech acts of suggestion spoken in Persian language, andPishghadam, et al [5], namely speech acts of suggestion spoken English by Iranian EFL learners. The data on the study are analyzed based on the scheme by Martinez-Flor[3] on the taxonomy of suggestions. Besides, to suggest strategies, Farnia, et al [4]also analyze mitigation devices using by the speakers in speech acts of suggestion. The results show that the speakers use non-verbal and verbal mitigation devices in conveying their suggestions.

\section{Method}

This study is a qualitative descriptive study. It involves 25 Indonesian students of Japanese as a Foreign Language consisting of 19 female students and 6 male students about 18-25 years old. This study uses a pragmatic approach to examining the speech produced by the students. The data of this study are verbal speech in the form of writing consisting of suggestions given by students to their interlocutors during peer response activity conducted through Facebook. This peer response activity is a part of the Japanese writing class carried out from October to December 2017. The data are classified based on the taxonomy of suggestion strategies by Martinez-Flor[3]. Meanwhile, data in the form of speeches aimed at preventing face-threatening acts are categorized into mitigation devices, later categorized by referring to the scheme created by Farnia, et al [ 4].In addition to speeches in the form of writing, interviews are conducted to confirm the findings

\section{Results and Discussion}

\subsection{Suggestion strategies}

Suggestion strategies used by the learners can be seen in the following in Table 1 below. 
Table 1.Suggestion strategies used by the learners.

\begin{tabular}{|c|c|c|c|c|}
\hline Type & Strategy & Frequency & \multicolumn{2}{|c|}{ Percentage } \\
\hline \multirow[t]{4}{*}{ Direct } & Performative verb & 2 & $5 \%$ & $28 \%$ \\
\hline & Noun of Suggestion & 8 & $12 \%$ & \\
\hline & Imperative & 8 & $12 \%$ & \\
\hline & Negative imperative & 0 & $0 \%$ & \\
\hline \multirow[t]{5}{*}{$\begin{array}{l}\text { Conventionalized } \\
\text { Forms }\end{array}$} & $\begin{array}{l}\text { Specific Formulae } \\
\text { (interrogative forms) }\end{array}$ & 9 & $14 \%$ & $32 \%$ \\
\hline & Possibility/Probability & 5 & $8 \%$ & \\
\hline & Should & 0 & $0 \%$ & \\
\hline & Need & 3 & $5 \%$ & \\
\hline & Conditional & 4 & $6 \%$ & \\
\hline \multirow[t]{3}{*}{ Indirect } & $\begin{array}{l}\text { Impersonal Martinez- } \\
\text { Flor (2005) }\end{array}$ & 25 & $38 \%$ & $40 \%$ \\
\hline & Hints & 1 & $2 \%$ & \\
\hline & Total & 65 & $100 \%$ & $100 \%$ \\
\hline
\end{tabular}

Based on table 1, it can be seen that the learners use speech act strategies of direct, conventionalized forms, and indirect. The most widely used strategy is an indirect strategy (40\%), followed by a conventionalized forms strategy (32\%), while the least used strategy is a direct $(28 \%)$. Indonesians recognize the culture of feeling reluctant or bad when offending others. With such a culture, they always try to maintain a harmonious relationship with others. For the Indonesians, it is highly important because it relates to saving the face of others. This cultural background is assumed to affect the strategy used when conducting speech acts of suggestion. This cultural background likely makes the learners prefer to use indirect strategies when giving suggestions. By using indirect strategy, the possibility of threatening the face of others becomes smaller.

When observed in a more detailed manner, the most widely used strategy is an impersonal strategy $(38 \%)$ that is a part of the indirect strategy. The impersonal strategy is an indirect strategy that does not directly ask the interlocutors to perform the activities suggested. From the data, it can be seen that the speakers are cautious in giving suggestions to save the face of the interlocutors by choosing this strategy.

\subsection{Mitigation devices}

To mitigate the suggestions, the learners also use various mitigation devices. Mitigation devices used by the learners can be seen in the following Table 2 below. 
Table 2. Mitigation Devices Used by the Learners.

\begin{tabular}{|c|c|c|c|c|c|}
\hline \multirow{2}{*}{$\begin{array}{c}\text { Type } \\
\text { Verbal }\end{array}$} & \multicolumn{2}{|r|}{ Mitigation } & \multirow{2}{*}{$\frac{\text { Frequency }}{15}$} & \multicolumn{2}{|r|}{ Percentage } \\
\hline & Opener & Greeting Words & & $8 \%$ & $57 \%$ \\
\hline & & Interjections & 7 & $4 \%$ & \\
\hline & & Names & 39 & $21 \%$ & \\
\hline & & Compliments & 40 & $21 \%$ & \\
\hline & & Benefits & 6 & $3 \%$ & \\
\hline & & Opening Words & 2 & $1 \%$ & \\
\hline & Justificati & Imperative & 3 & $2 \%$ & $5 \%$ \\
\hline & on/Reason & Noun of Suggestion & 2 & $1 \%$ & \\
\hline & & Impersonal & 3 & $2 \%$ & \\
\hline & & Interrogative Forms & 1 & $1 \%$ & \\
\hline & & Possibility/Probability & 1 & $1 \%$ & \\
\hline & Hedges & $\begin{array}{l}\text { Mungkin/kayaknya/sep } \\
\text { ertinya (maybe) }\end{array}$ & 12 & $6 \%$ & $6 \%$ \\
\hline & \multicolumn{2}{|c|}{$\begin{array}{l}\text { Words Cuma/Paling/hanya } \\
\text { (just/only) }\end{array}$} & 24 & $13 \%$ & $13 \%$ \\
\hline & \multicolumn{2}{|c|}{ Phatic expression } & 9 & $5 \%$ & $5 \%$ \\
\hline & Closing & $\begin{array}{l}\text { Terimakasih(Thank } \\
\text { you) }\end{array}$ & 3 & $2 \%$ & $4 \%$ \\
\hline & & Compliments & 4 & $2 \%$ & \\
\hline Non- & & Emoticon & 14 & $7 \%$ & $10 \%$ \\
\hline \multirow[t]{2}{*}{ Verbal } & \multirow{2}{*}{\multicolumn{2}{|c|}{$\begin{array}{l}\text { Laughing forms } \\
\text { Total }\end{array}$}} & 5 & $3 \%$ & \\
\hline & & & 190 & $100 \%$ & $100 \%$ \\
\hline
\end{tabular}

Based on table 2, it can be seen that the most common type of mitigation devices is opener $(57 \%)$, followed by the words cuma/paling/hanya (just/only) (13\%), nonverbal mitigation devices $(10 \%)$, hedges $(6 \%)$, justification/reason $(5 \%)$, phatic expression $(5 \%)$, and closing (4\%). When observed in more detailed manner, the most widely used strategy is compliment $(21 \%)$ and names $(21 \%)$, followed by the words cuma/paling/hanya (just/only) (13\%), greeting words $(8 \%)$, emoticon $(7 \%)$, and hedges $(6 \%)$.

In this study, it is obvious that many learners use compliments in openers. Compliments are used to mitigate the threat to the face of the interlocutors. Besides, names are also widely used, particularly in openers. This peer response activity is carried out in groups consisting of 4-5 people since names are always used to greet the interlocutors who will be given suggestions. By mentioning names, it may make the speech acts of suggestion more successful. The words cuma/paling/hanya (just/only) are used to mitigate the suggestions used. By using the word, the speakers expect to lessen the burden that the interlocutors feel. Besides, greeting words are also widely used in the opener. Therefore, the delivery of suggestions will be softer and easier to accept.

In this study, non-verbal mitigation devices are also found in the form of emoticons and laughing forms. The most widely used emoticons are smiley emoticons such as :), (), ^^, etc. These emoticons serve to mitigate the suggestions given by the speakers. Indirect communication, a smile is used to mitigate face-threatening acts to the interlocutors given the suggestions. It is expressed in the form of emoticons in written symbols. Moreover, to mitigate face-threatening acts, several learners are using laughing forms. In Bahasa Indonesia, there are several laughing forms such as hehehe, hahaha, hihihi, wkwkwk. Hahaha, hihihi, wkwkwkw are used when the speakers find something funny or ridiculous, while hehehe is used to mitigate the speeches supposed to offend the interlocutors. The hedges used by the learners are 
the words mungkin/kayaknya/sepertinya (maybe). The words are used as hedges to save the face of the speakers. The words mungkin/kayaknya/sepertinya contain uncertainty of the speakers about the speech delivered.

\section{Conclusions}

From the study, it can be concluded that the learners use indirect strategy more frequently when performing speech acts of suggestion. Besides, to mitigate the threat to the interlocutors, the learners frequently use mitigation devices. Thus, it can be said that Indonesian learners tend to convey suggestions indirectly. They are highly cautious to save the faces of the interlocutors and themselves. These face-saving acts are carried out even when they interact with their peers. It is in line with the culture of Indonesians to maintain a harmonious relationship between the speakers and the interlocutors. So that peer response activity takes place smoothly and the learners can participate actively, special treatment is necessary, for example, by explaining the importance and benefits of peer response activity for improving writing skills.

Acknowledgments. The authors gratefully acknowledge the use of the services and facilities of the International Seminar Grant at the University of Al Azhar Indonesia, funded by LP2M UAI.

\section{References}

[1] R. Ikeda and Y. Tateoka, Piaraaningu Nyuumon Souzoutekina Manabi no Dezain no tame. Tokyo: Hitsujishoshou, 2007.

[2] P. Brown and S. C. Levinson, Politeness: Some Universals in Language Usage. New York: Cambridge University Press, 1987.

[3] A. Martinez-Flor, "A theoretical review of the speech act of suggesting: Towards a taxonomy for its use in FLT," Rev. Alicant. de Estudios Ingleses, vol. 18, pp. 167-187, 2005.

[4] M. Farnia, A. Sohrabi, and H. Q. A. Sattar, "A Pragmatic Analysis of Speech Act of Suggestion among Iranian Native Speaker of Farsi," J. ELT Appl. Linguist., vol. 2, no. 2, pp. 48-60, 2014.

[5] R. Pishghadam and M. Sharafadini, "Delving into speech act of suggestion: A case of Iranian EFL learners international,” J. Bus. Soc. Sci., vol. 2, no. 16, pp. 152-160, 2011. 